\title{
DEPOSITO SEBAGAI JAMINAN KREDIT BERDASARKAN UNDANG-UNDANG PERBANKAN
}

\author{
Asuan \\ Fakultas Hukum Universitas Palembang \\ E-mail: asuan.okay@gmail.com
}

\begin{abstract}
$\overline{\text { Time deposit is a banking product, namely customers who deposit their money within a certain }}$ period of time in a bank (according to the agreement between the customer and the bank), which earns deposit interest. Deposits as collateral in the credit agreement between the debtor / customer and creditor / bank. in the provision of credit which may not exceed 95\% of the value of deposits with a credit period of 60 months at the longest, based on Article 1 point 7 of Law Number 10 of 1998 concerning Banking. If there is a default based on article 1238 of the Civil Code, then the creditor as the credit provider commits legal actions, namely warning letters, summons and execution and settlement through a lawsuit to the Court, then through the State Receivables Affairs Committee and the State Receivables Affairs Committee based on Law Number 49 of the Year 1960 Concerning the Committee for State Receivables Affairs.
\end{abstract}

Keywords: deposits; default

\section{Abstrak}

Deposito merupakan salah satu produk perbankan, yaitu nasabah yang menyimpankan uangnya dalam jangka waktu tertentu suatu bank (sesuai kesepakatan antara nasabah dan pihak bank) diperoleh bunga deposito. Deposito sebagai jaminan dalam perjanjian kredit antara debitur/nasabah dan kreditur/bank. dalam pemberian kredit yang tidak boleh melebih $95 \%$ nilai deposito dengan waktu kreditnya 60 bulan paling lama, berdasarkan Pasal 1 butir 7 UndangUndang Nomor 10 Tahun 1998 tentang Perbankan. Jika terjadi wanprestasi berdasarkan pasal 1238 KUH Perdata, maka kreditur sebagai pemberi kredit melakukan perbuatan hukum yaitu surat peringatan, surat somasi dan eksekusi dan penyelesaian melalui gugatan ke Pengadilan, selanjutnya melalui Panitia Urusan Piutang Negara Dan Badan Urusan Piutang Negara berdasarkan Undang-Undang Nomor 49 Tahun 1960 Tentang Panitia Urusan Piutang Negara.

Kata Kunci: deposito; wanprestasi

\section{PENDAHULUAN}

Perbankan merupakan suatu perusahaan yang bergerak di bidang jasa. Dimana bank adalah penyalur dana dari masyarakat yang mempunyai dana lebih kepada masyarakat yang membutuhkan dana serta sebagai tempat untuk menghimpun dana masyarakat itu sendiri. Faktor kepercayaan dari masyarakat adalah hal yang utama dalam bisnis perbankan. ${ }^{1}$

Menghimpun dan menyalurkan dana masyarakat merupakan fungsi utama dari Perbankan Indonesia. Bank menghimpun dana masyarakat kedalam

\footnotetext{
1 Muhamad Djumanha, Hukum Perbankan di Indonesia (Bandung: Citra Aditya Bakti, Bandung, 1996).
} 
Asuan, Deposito Sebagai Jaminan Kredit Berdasarkan Undang-Undang Perbankan, Halaman 351-370

bentuk giro, deposito, tabungan, serta bentuk-bentuk lainnya, sedangkan yang dimaksud sebagai penyalur dana masyarakat merupakan peberian fasilitas kredit oleh bank untuk masyarakat.

Salah satu kegiatan yang pokok bagi bank adalah berupa pemberian kredit yang sering disebut dengan kredit perbankan. Pelaksanaan pemberian kredit biasanya dikaitkan dengan berbagai persyaratan, antara lain mengenai jumlah maksimal kredit, jangka waktu kredit, tujuan penggunaan kredit, suku bunga kredit, cara penarikan dana kredit, dan jadwal pelunasan kredit. ${ }^{2}$

Dalam proses pemberian kredit perbankan antara bank dengan debitur dilakukan dengan membuat suatu perjanjian. Perjanjian kredit itu terbagi atas perjanjian utang piutang antara bank sebagai kreditur.dengan debitur itu sendiri yang disebut sebagai perjanjian pokok, serta diikuti perjanjian accesoir atau perjanjian tambahan yang meliputi pemberian jaminan oleh pihak debitur kepada pihak bank. Pengikatan jaminan merupakan bentuk antisipasi oleh pihak bank apabila

${ }^{2}$ M. Bahsan, Hukum Jaminan dan Jaminan Kredit Perbankan Indonesia (Jakarta: PT. Rajagrafindo Persada, 2015). debitur tidak mau membayar kewajibannya atau utang-utangnya.

Unsur dasar berupa kepercayaan harus ada pada saat proses pemberian kredit di bank, dimana pihak bank selaku pemberi kredit percaya kepada debitur yang menerima kredit agar dapat mengembalikan pinjaman yang nantinya akan menjadi untung dari bank itu sendiri. Guna memperoleh kepercayaan itu, modal debitur, kemampuannya, watak, agunannya, serta usaha yang dimiliki debitur harus dinilai oleh bank terlebih dahulu sebelum memberikan kredit. ${ }^{3}$

Fungsi jaminan dalam pemberian kredit bank merupakan source of the last resort bagi pelunasan kredit yang diberikan oleh bank kepada nasabah artinya, bila ternyata sumber utama pelunasan nasabah yang hasilnya diperoleh dari usaha debitur tidak memadai, maka hasil eksekusi dari jaminan itu diharapkan menjadi sumber pelunasan alternatif terakhir yang dapat diharapkan oleh bank dari debitur tersebut.

Jaminan yang diterima kreditur dapat berupa benda ataupun berupa hak tagih atas proyek yang dibiayai dengan

\footnotetext{
3 Hermansyah, Hukum Perbankan Nasional Indonesia (Jakarta: Prenana Media, 2005).
} 
Asuan, Deposito Sebagai Jaminan Kredit Berdasarkan Undang-Undang Perbankan, Halaman 351-370

kredit (agunan pokok) dan agunan jangka waktu yang ditentukan, Prinsip tambahan yaitu agunan yang diberikan debitur. Adapun jenis agunan itu sendiri dapat dibedakan menjadi 2 macam yaitu berupa jaminan materiil (kebendaan) dan jaminan imateriil (perorangan). ${ }^{4}$

Dalam hal ini banyak perbankan di Indonesia memberikan pemberian kredit dengan jaminan berupa deposito berjangka. Dalam Undang-Undangr Nomor 10 Tahun 1998 tentang Perbankan Pasal 1 angka 7 terdapat pengertian mengenai deposito yaitu simpanan yang penarikannya hanya dapat dilakukan pada waktu tertentu berdasarkan perjanjian nasabah dengan bank. Di prakteknya, seringkali jaminan ini jarang diperhatikan oleh para praktisi perbankan, sehingga nantinya akan mengakibatkan terjadinya pengikatan yang kurang berarti secara yuridis. Upaya tersebut dilakukan pihak bank dengan tujuan untuk mempersingkat realisasi kreditnya. Pengikatan dengan jaminan deposito berjangka berbedabeda di setiap bank, hal itu disesuaikan dengan kebijakan dari bank itu sendiri. Agar tujuan pemberian kredit dapat terpenuhi dan prestasi dapat kembali sesuai dengan

${ }^{4}$ Salim, HS, Perkembangan Hukum Jaminan di Indonesia (Jakarta: PT. Rajagrafindo Persada, 2004). kehati-hatian perlu diperhatikan dalam menjalankan usaha perbankan, terutama dalam penyaluran dana kemasyarakat/kredit bank haruslah melakukan analisis yang mendalam, mulai dari proses awal pengajuan kredit sampai pencairan kredit, proses perjanjian dan pemenuhan dokumendokumen kredit yang lengkap.

Menurut pasal 2 UU Nomor 10

Tahun 1998 Tentang Perbankan disebutkan "bahwa perbankan dalam melakukan usahanya berdasar demokrasi ekonomi dan prinsip kehatihatian." Penerapan prinsip kehati-hatian dalam proses analisa kredit penyaluran dana ke masyarakat akan meminimalisir resiko dalam kredit yang akan disalurkan. Resiko kredit adalah kerugian yang disebabkan oleh debitur dalam jangka waktu yang telah disepakati tidak dapat mengembalikan hutang yang dipinjam kepada bank.

. Penghimpun dana dan pemberian kredit merupakan pelayanan jasa perbankan yang utama dari semua kegiatan lembaga keuangan bank. Bank Umum maupun Bank Perkreditan Rakyat, keduanya dapat melakukan kegiatan penghimpun dana. Pelayanan jasa berupa 
Asuan, Deposito Sebagai Jaminan Kredit Berdasarkan Undang-Undang Perbankan, Halaman 351-370

penghimpun dana dari masyarakat dapat berupa simpanan giro, deposito berjangka, sertifikat deposito, tabungan, dan atau bentuk lainnya yang dipersamakan dengan itu. Bentuk lainnya yang dipersamakan dengan itu dimaksudkan untuk menampung kemungkinan adanya bentuk penghimpunan dana dari masyarakat oleh Bank Perkreditan Rakyat yang serupa dengan depositoberjangka dan tabungan tetapi bukan giro atau simpanan lain yang dapat ditarik dengan cek. $^{5}$

Deposito berjangka merupakan salah satu produk yang ditawarkan oleh bank bagi para nasabah yang ingin menyimpankan uangnya dalam jangka waktu tertentu (sesuai kesepakatan antara nasabah dan pihak bank), lalu dari uang yang disimpan itu diperoleh bunga deposito yang diperuntukkan bagi si nasabah. Fasilitas kredit yang diberikan oleh bank salah satunya adalah menjadikan deposito berjangka sebagai jaminan dalam perjanjian kredit antara debitur/nasabah dan kreditur/bank.Jaminan kredit dengan deposito berjangka ini juga mempermudah kegiatan kredit antara debitur dan kreditur, karena ini

${ }^{5}$ Muhamad Djumhana, Hukum Perbankan di Indonesia memungkinkan pihak bank mampu menyalurkan kredit kepada masyarakat bersumber dari dana yang disimpan oleh masyarakat itu sendiri. Pemberian kredit dengan jaminan deposito berjangka ini juga mampu mempercepat proses kredit dan aman bagi nasabah. Dan begitu pula dengan pihak bank menimbulkan rasa aman untuk memberikan kredit kepada nasabah.

Oleh karenanya, pemberian kredit tersebut secara terus menerus dilakukan oleh bank dalam kesinambungan operasionalnya. Pada akhirnya, pemberian kredit sudah menjadi fungsi utama bank-bank, sebagaimana diisyaratkan pada Pasal 3 UndangUndang Nomor 7 Tahun 1992 jo Undang-Undang Nomor 10 Tahun 1998 tentang Perbankan, bahwa fungsi utama perbankan Indonesia adalah sebagai penghimpun dana dan penyalur dana masyarakat. ${ }^{6}$

Deposito berjangka merupakan salah satu produk yang ditawarkan oleh bank bagi para nasabah yang ingin menyimpankan uangnya dalam jangka waktu tertentu (sesuai kesepakatan antara nasabah dan pihak bank), lalu dari uang yang disimpan itu diperoleh

\footnotetext{
${ }^{6}$ O.P.Simorangkir, Kamus Perbankan (Jakarta: Bina Aksara, 1989).
} 
Asuan, Deposito Sebagai Jaminan Kredit Berdasarkan Undang-Undang Perbankan, Halaman 351-370

bunga deposito yang diperuntukkan bagi si nasabah. Fasilitas kredit yang diberikan oleh bank salah satunya adalah menjadikan deposito berjangka sebagai jaminan dalam perjanjian kredit antara debitur/nasabah dan kreditur/bank. Jaminan kredit dengan deposito berjangka ini juga mempermudah kegiatan kredit antara debitur dan kreditur,karena ini memungkinkan pihak bank mampu menyalurkan kredit kepada masyarakat bersumber dari dana yang disimpan oleh masyarakat itu sendiri. Pemberian kredit dengan jaminan deposito berjangka ini juga mampu mempercepat proses kredit dan aman bagi nasabah. Dan begitu pula dengan pihak bank menimbulkan rasa aman untuk memberikan kredit kepada nasabah.

Dalam menyalurkan kredit kepada masyarakat akan membawa resiko kredit, yang dimaksud dengan risiko kredit adalah "risiko kerugian sehubungan dengan pihak peminjam tidak dapat dan atau tidak mau memenuhi kewajiban untuk membayar kembali dana yang dipinjamnya secara penuh pada saat jatuh tempo atau sesudahnya. Dalam kegiatan kredit perbankan proses analisa kredit adalah salah proses terpenting yang harus dilakukan secara cermat oleh pihak bank karena melalui proses analisa yang baik akan mengurangi resiko dalam proses kredit perbankan.

Permasalahannya yaitu bagaimana perjanjian pemberian kredit dengan jaminan deposito menurut Undang-Undang Nomor 10 tahun 1998 tentang Perbankan, serta penyelesaian terhadap debitur terjadi wanprestasi dalam perjanjian kredit tersebut.

\section{PEMBAHASAN}

\section{A. Deposito Sebagai Jaminan Perjanjian Kredit Menurut Undang-Undang Nomor 10 tahun 1998 tentang Perbankan}

Perjanjian kredit merupakan perjanjian pendahuluan (pactum de contrahendo). Dengan demikian perjanjian ini mendahului perjanjian hutang- piutang (perjanjian pinjam mengganti). Sedang perjanjian hutangpiutang merupakan pelaksanaan dari perjanjian pendahuluan dan perjanjian kredit. Kiranya uraian masalah ini cukup jelas jika arti pendahuluan pada perjanjian kredit dibedakan dengan arti pelaksanaan perjanjian hutang-piutang. ${ }^{7}$

Perjanjian kredit (PK) menurut

\footnotetext{
${ }^{7}$ Hartono Soerja Pratiknyo, Hutang Piutang (Yogyakarta: Mustika Wikasa, 1989).
} 
Asuan, Deposito Sebagai Jaminan Kredit Berdasarkan Undang-Undang Perbankan, Halaman 351-370

Hukum Perdata Indonesia merupakan salah satu dari bentuk perjanjian pinjam meminjam yang diatur dalam buku ketiga KUH Perdata. Dalam bentuk apapun juga pemberian kredit itu diadakan pada hakikatnya merupakan salah satu perjanjian pinjam meminjam sebagaimana diatur dalam Pasal 1754 sampai dengan Pasal 1769 KUH Perdata. Namun demikian dalam praktek perbankan yang modern, hubungan hukum dalam kredit tidak lagi sematamata berbentuk hanya perjanjian pinjam-meminjam saja melainkan adanya campuran dengan bentuk perjanjian yang lainnya seperti perjanjian pemberian kuasa, dan perjanjian lainnya. Dalam bentuk yang campuran demikian maka selalu tampil adanya suatu jalinan diantara perjanjian yang terkait tersebut. Namun demikian dalam praktek perbankan pada dasarnya bentuk dan pelaksanaan perjanjian pinjam meminjam yang ada dalam KUH Perdata tidaklah sepenuhnya identik dengan bentuk dan pelaksanaan suatu perjanjian kredit perbankan, diantara keduanya ada perbedaanperbedaan yang gradual bahkan dapat pula merupakan perbedaan yang pokok. $^{8}$

${ }^{8}$ Muhamad Djumhana, Hukum Perbankan di Indonesia
Undang-undang yang berlaku di Indonesia tentang perjanjian kredit belum diatur secara tegas, UndangUndang Nomor 10 Tahun 1998 dalam Pasal 1 angka (11) tidak dijumpai pengertian perjanjian kredit, hanya ditemukan “...berdasarkan persetujuan atau kesepakatan pinjam-meminjam antara bank dengan pihak lain...", demikian pula dalam penjelasan undang-undang tersebut tidak dijumpai pengertian lebih lanjut tentang pengertian kredit.

Pengertian kredit pada Pasal 1 angka (11) UU Nomor 10 Tahun 1992 tentang Perbankan dapat dipahami bahwa setiap bank memberikan kredit kepada nasabah debitur dituangkan dalam suatu perjanjian kredit berdasarkan persetujuan atau kesepakatan kedua belah pihak yakni pihak bank dan pihak peminjam (debitur).

Pembuatan perjanjian kredit tersebut diperlukan dalam rangka memberikan kepastian hukum bagi para pihak, sehingga apabila terjadi permasalahan dikemudian hari maka para pihak yang berkepentingan dalam perjanjian kredit yang telah dibuat sebagai dasar hukum untuk menuntut 
Asuan, Deposito Sebagai Jaminan Kredit Berdasarkan Undang-Undang Perbankan, Halaman 351-370

pihak yang telah dirugikan. ${ }^{9}$

Secara yuridis ada 2 (dua) jenis perjanjian atau pengikatan kredit yang digunakan dalam bank untuk memberikan kredit nya, yaitu:

a. Perjanjian/pengikatan kredit dibawah tangan atau akta dibawah tangan;

b. Perjanjian/pengikatan kredit yang dibuat oleh dan dihadapan notaris (notariil) atau akta otentik.

Akta/perjanjian kredit dibawah tangan, yang dimaksud dengan akta perjanjian kredit dibawah tangan adalah perjanjian pemberian kredit oleh bank kepada nasabahnya yang dibuat hanya diantara mereka (kreditur dan debitur) tanpa notaris. Lazimnya dalam penandatanganan akta perjanjian kredit, saksi turut serta membubuhkan tanda tangannya karena saksi merupakan salah satu alat pembuktian dalam perkara perdata.

Akta/perjanjian kredit notariil (otentik), yang dimaksud dengan akta perjanjian kredit notariil (otentik) adalah perjanjian pemberian kredi oleh bank kepada nasabahnya yang hanya dimuat oleh atau dihadapan notaris ${ }^{10}$.

\footnotetext{
9 Bambang Fitrianto, Hukum Jaminan Perjanjian Kredit Kepemilikan Rumah (Medan: Pustaka Bangsa Press, 2013).

${ }^{10}$ Budi Untung, Kredit Perbankan di Indonesia (Yogyakarta: Andi, 2000).
}

Adapaun akta otentik diartikan sebagai akta yang dibuat dalam bentuk yang telah ditentukan oleh undang-undang, dibuat oleh atau di hadapan pegawai umum yang berkuasa untuk itu, ditempat dimana akta dibuatnya. ${ }^{11}$

Kegiatan menjalankan perjanjian tersebut maka antara pihak debitur dan kreditur dibuat suatu perjanjian kredit dalam bentuk tertulis yang dibuat dan disusun agar para pihak dengan mudah memahami isi dari perjanjian tersebut dan perjanjian kredit itu dianggap sah sebagai sebuah alat bukti. Jaminan kredit diartikan sebagai penyerahan kekayaan atau pernyataan kesanggupan seseorang untuk menanggung pembayaran kembali suatu utang.

Perjanjian pokok tersebut dalam hal ini adalah perjanjian kredit bank. Berbeda halnya jika jaminan yang diterima oleh bank hanyalah berbentuk benda atau tagihan yang memiliki sifat fluktuatif dari segi nilai (jika dieksekusi). Sehubungan dengan hal di atas, maka timbul beberapa masalah yang hendak dikaji oleh penulis yaitu mengenai perjanjian kredit dengan jaminan deposito.

\footnotetext{
${ }^{11}$ Herlien Soerojo, Kepastian Hukum Hak Atas Tanah di Indonesia (Surabaya: Arkola, 2003).
} 
Asuan, Deposito Sebagai Jaminan Kredit Berdasarkan Undang-Undang Perbankan, Halaman 351-370

Pengertian deposito menurut Undang-Undang Nomor 10 Tahun 1998 tentang Perbankan pada Pasal 1 angka 7, simpanan yang penarikannya hanya dapat dilakukan pada waktu tertentu berdasarkan perjanjian nasabah penyimpan dengan bank. Pemilikan atas deposito ini dibuktikan dengan suatu surat yang dikenal dengan bilyet deposito. Deposito dilihat dari asal usul kata berasal dari bahasa Inggris“"deposit” dari kata "timedeposit" yang artinya simpanan uang yang penarikannya kembalihanya dapat dilakukan setelah jangka waktu tertentu sesuai dengan perjanjian antara deposan dan depositaris. Deposan adalah masyarakat penyimpan dana baik perorangan maupun badan hukumatau badan lainnya yang mendepositokan uangnya pada bank. Sedangkan depositaris adalah terdiri dari bank-bank yang telah mendapatkan ijin dari Bank Indonesia dalam menerima simpanan deposi to berjangka.

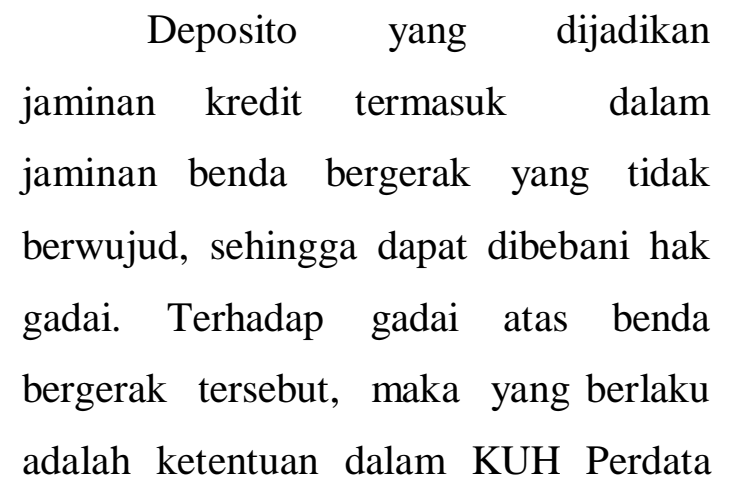
dari Pasal 1150 sampai dengan Pasal 1160. Menurut Pasal 1150 KUH Perdata gadai dirumuskan sebagai berikut:

"Gadai adalah suatu hak yang diperoleh seorang yang berpiutang atas suatu barang bergerak, yang diserahkan kepadanya oleh seorang berutang atau oleh seorang lain atas namanya, dan yang memberikan kekuasaan kepada si berpiutang itu untuk mengambil pelunasan dari barang tersebut secara didahulukan daripada orang-orang berpiutang lainnya; dengan kekecualian biaya untuk melelang barang tersebut dan biaya yang telah dikeluarkan untuk menyelamatkannya setelah barang itu digadaikan, biaya-biaya mana yang harus didahulukan."

Hak gadai terjadi dengan penyerahan benda gadai secara nyata sehingga benda tersebut berada di bawah kekuasaan kreditur. Hak kebendaan (jaminan) atas benda bergerak itu dan pada pemegang gadai. Hal tersebut tercantum dalam Pasal 1152 ayat (1) KUH Perdata:

"Hak gadai atas benda-benda bergerak dan atas piutang- piutang bawa diletakkan dengan membawa barang gadainya dibawah kekuasaan si berpiutang atau 
Asuan, Deposito Sebagai Jaminan Kredit Berdasarkan Undang-Undang Perbankan, Halaman 351-370

seorang pihak ketiga, tentang siapa yang telah disetujui oleh kedua belah pihak."

Sebagaimana dijelaskan Pasal 1 butir 7 UU Perbankan bahawa deposito sebagai jaminan kredit oleh bank tentu menjadi suatu hal yang sangat menguntungkan, karena dari sisi ketersediaan nilai yang akan diperoleh oleh bank ketika suatu kredit telah menjadi bermasalah dapat dikatakan telah terjamin (kepastian penerimaan kembali kredit yang diberikan). Deposito sebagai jaminan utang merupakan benda bergerak dan deposito adalah salah satu objek jaminan gadai. Gadai merupakan hak jaminan kebendaan, yang timbul dari perjanjian gadai. Perjanjian gadai ini tidak berdiri sendiri tetapi merupakan perjanjian ikutan atau accessoir dari perjanjian pokoknya. ${ }^{12}$

Tata cara pengikatan deposito sebagai jaminan kredit adalah sebagai berikut:

1. Pengikatan deposito dilakukan dengan pembuatan akta perjanjian gadai antara pemilik deposito dengan pihak bank. Menurut

12 J.Satrio, Hukum Jaminan, Hak-hak Jaminan Kebendaan (Bandung: PT. Citra Aditya Bakti, 1998). hukum, akta perjanjian gadai dapat dibuat secara sah dengan dilakukan secara notariil maupun di bawah tangan, yang dibuat untuk mendukung perjanjian hutang pokok yang biasanya berupa perjanjian hutang-piutang.

2. Untuk membebankan hak gadai maka setelah pembuatan akta perjanjian gadai antara pemilik deposito dengan pihak bank, selanjutnya diikuti dengan penyerahan bilyet deposito yang akan "dijaminkan kepada pemegang gadai, dalam hal ini pihak bank. Penyerahan tersebut merupakan penyerahan yang nyata, tidak boleh hanya berdasarkan pada pernyataan dari pemberi gadai saja, tetapi benda itu masih berada dalam kekuasaannya. Penyerahan yang nyata ini bersamaan dengan penyerahan yuridis, sehingga penyerahan tersebut merupakan unsur sahnya gadai. ${ }^{13}$

Pasal 8 UU No. 10 tahun 1998 tentang Perbankan menyebutkan :

13 Sihombing, Jonker, Penjaminan Simpanan Nasabah Perbankan (Bandung: PT.Alumni, Bandung, 2010). 
Asuan, Deposito Sebagai Jaminan Kredit Berdasarkan Undang-Undang Perbankan, Halaman 351-370

1. Dalam memberikan kredit atau pembiayaan berdasarkan Prinsip Syariah, Bank Umum wajib mempunyai keyakinan berdasarkan analisis yang mendalam atau itikad baik dan kemampuan serta kesanggupan Nasabah Debitur untuk melunasi utangnya atau mengembalikan pembiayaan dimaksud sesuai dengan yang diperjanjikan.

2. Bank Umum wajib memiliki dan menerapkan pedoman perkreditan dan pembiayaan berdasarkan Prinsip Syariah, sesuai dengan ketentuan yang ditetapkan oleh Bank Indonesia

Berdasarkan uraian diatas bahwa pemilik deposito/debitur harus memberikan kuasa kepada pemegang gadai/pihak bank untuk melakukan pencairan deposito dalam hal pemilik deposito/debitur wanprestasi untuk memudahkan kreditur mengambil pelunasan. Sebagai salah satu bentuk jaminan likuid, jenis deposito yang dapat dijadikan jaminan kredit pada bank.

Deposito menurut janka waktu penempatannya terbagi atas deposito dengan jangka waktu 1 bulan, 3 bulan, 6 bulan dan 12 bulan.
Apabila deposito dicairkan sebelum tanggal jatuh tempo maka akan dikenakan denda dan bunga yang berjalan pada bulan tersebut tidak dibayarkan. Menurut ketentuan suku bunganya adalah suku bunga penjaminan yang ditetapkan oleh Bank Indonesia. Pada saat ini suku bunga deposito pada Bank adalah 7 $\%$ pertahun hal tersebut berlaku untuk semua jangka waktu deposito.Dijelaskan pula bahwa bunga kredit adalah 2\% diatas suku bunga deposito sehingga bunga kredit menjadi $9 \%$ pertahun. (sebagaimana dimana disebutkan dalam Pasal 6 bagian b butir 7 UU No. 10 Tahun 1998 tentang Perbankan).

Pihak lembaga keuangan bank memberikan batasan maksimum fasilitas kredit yang dapat diberikan kepada calon debitur adalah $95 \%$ dari nilai depositonya, pemberian jaminan deposito ini berlaku bagi deposan yang baru serta tidak memiliki jenis tabungan yang lain. Sedangkan bagi deposan yang memiliki jenis tabungan yang lain pihak bank berani mengasih sama dengan nilai deposito $100 \%$ hal ini dilakukan bank atas 
Asuan, Deposito Sebagai Jaminan Kredit Berdasarkan Undang-Undang Perbankan, Halaman 351-370

kehati-hatiannya dalam

memberikan pinjaman terhadap

konsumen. Disamping itu jangka waktu antara fasilitas yang diberikan dengan jangka waktu deposito sebagai jaminan juga harus disesuaikan antara kepentingan debitur dalam penggunaan fasilitas kredit dan kepentingan pihak Bank dalam pemberian kreditnya agar tetap aman tidak dirugikan.

Dalam praktek perbankan pelaksanaan perjanjian kredit harus dituangkan dalam bentuk tertulis yang umumnya dibuat secara notaril dan di bawah tangan. Memperhatikan ketentuan diatas bahwa pelaksanaan perjajian kredit dengan jaminan deposito di bank dilakukan dengan pengikatan di bawah tangan. Hal tersebut berdasarkan pertimbangan bahwa jaminan deposito adalah merupakan salah satu jaminan yang aman bagi bank, karena apabila terjadi wanprestasi maka proses penguangannya cukup mudah yaitu hanya melakukan pencairan dana deposito tersebut.

Pengikatan jaminan tersebut dilaksanakan dengan persetujuan gadai atas tagihan tunai, surat kuasa untuk memblokir dan mencairkan serta perjanjian kredit. Dalam pelaksanaan pemberian kredit dengan jaminan deposito terdapat perbedaan persyaratan dibandingkan dengan pemberian kredit dengan jaminan diluar jaminan deposito pada umumnya. Perbedaan ini antara lain :

1. Jumlah lebih tinggi, dana yang dibutuhkan dalam pinjaman diberikan hampir sama dengan nilai jaminan tersebut

2. Prosedur mudah, murah, sederhana dalam pemberian perjanjian kredit dengan jaminan deposito pelaksanaannya tidak berliku liku atau berbelit belit karena jaminan telah ada dan nyata disimpan bank dalam bentuk deposito, pelaksanaan tersebut tidak perlu mengeluarkan dana dan prosesnya cepat sehingga dana cepat langsung dipakai untuk kegiatan pendanaan usaha nasabah.

3. Suku bunga rendah, dana yang dikeluarkan atas bunga dari pinjaman sangat kecil yakni hanya $2 \%$ pertahun, beda dengan jaminan kebendaan yang lain yakni 9\%. Hal ini karena dana jaminan deposito juga mendapat 
Asuan, Deposito Sebagai Jaminan Kredit Berdasarkan Undang-Undang Perbankan, Halaman 351-370 bunga $7 \%$, sehingga dengan itu.

pinjaman atas jaminan deposito

Dalam pemberian kredit dengan dana yang dikeluarkan betul betul rendah atas pinjaman tersebut. jaminan deposito kredit dapat digunakan sebagai berikut :

4. Tidak perlu survei kelayakan atas jaminan, dalam hal perjanjian kredit dengan jaminan deposito dimana pihak bank tidak perlu lagi repot repot untuk melihat dan mengecek kelapangan karena dana telah tersimpan dan waktu yang ada tidak terbuang sia- sia. Dalam deposito tidak disyaratkan adanya NPWP (Nomor Pokok Wajib Pajak), SIUP (Surat Izin Usaha Perdagangan) dan TDP (Tanda daftar Perusahaan), tetapi dalam deposito hanya diserahkan berupa bilyet deposito yang meliputi identitas debitur, bilyet deposito asli, nomor deposito, jangka waktu kredit dan atas nama. Mengenai provisi (biaya) deposito tidak dikenakan biaya, sedangka jaminan diluar deposito dikenakan biaya sebesar $1 \%$. Selain itu dalam jaminan angunan kas (cash Collateral) suku bunga pinjaman bersifat khusus yaitu suku bunga pinjaman dapat berubah karena mengukuti suku bunga deposito yang berlaku saat

1. Full Cash collateral, yaitu deposito deblitur dapat dijadikan sebagai jaminan utama, artinya deposito itu sepenuhnya dijadikan jaminan pada kreditur bank.

2. Parcial Cash Colleteral, yaitu deposito yang dijadikan sebagai jaminan kredit disamping masih ada jaminan yang lain yaitu berupa sertifikat.

Syarat syarat yang harus dipenuhi oleh nasabah yang menerima perjanjian kredit dengan jaminan deposito sebagai berikut :

1. Menyerahkan KTP (Kartu Tanda Penduduk)

2. Menyerahkan bilyet deposito yang asli

3. Debitur harus nasabah pada bank yang memberikan kredit

4. Membuat perjanjian kredit dan Surat perjanjian jaminan

5. Pemblokiran Deposito ${ }^{14}$

Prosedur pemberian kredit dengan jaminan deposito adalah sebagai berikut :

14 Sembiring, Sentosa, Hukum Perbankan (Bandung: CV Mandar Maju, 2008). 
Asuan, Deposito Sebagai Jaminan Kredit Berdasarkan Undang-Undang Perbankan, Halaman 351-370

1. Mengajukan permohonan kredit yang ditujukan kepada pimpinan bank yang dilampiri Bilyet Deposito Asli, foto copy KTP (kartu tanda penduduk) / Identitas pemilik deposito;

2. Diproses ke bagian kredit yaitu di bagian pengelolaan rekening;

3. Kemudian dianalisa yang meliputi analisa Peremohonan kredit yang dilakukan oleh petugas bank, dengan analisa ini petugas akan menentukan jumlah kredit yang diberikan kepada debitur dan jumlah kredit tidak boleh melebihi dari jumlah nilai deposito. Maksimum yang diberikan yakni $100 \%$ dari nilai deposito dengan pertimbangan debitur tercatat sebagai debitur yang baik dan memiliki dana pada jenis tabungan yang lain, karena pihak bank selalu berhati hati dalam memberikan pertimbangannya, bila nasabah (Deposan) baru dan tidak memiliki dana dalam bentuk tabungan yang lain hanya diberikan maksimal $95 \%$ dari jaminan;

4. Setelah dianalisa langkah berikutnya dilakukan dengan membubuhkan Acc (aproved) dilanjutkan ke CSA (bagian kredit dan legal) Acc (aproved) kembali ke markerting (Cotemer Service) untuk menandatangani perjanjian perjanjian. ${ }^{15}$

Pemberian kredit dengan jaminan deposito berjangka bank memberikan batasan maksimal fasilitas kredit yang dapat diberikan kepada calon debitur adalah sama dengan nilai deposito atau $100 \%$ bagi deposan lama serta memiliki jenis tabungan lain, bila tidak bank hanya berani memberikan pinjaman yakni sebesar $95 \%$ dari nilai depositonya. Ini berarti besarnya fasilitas kredit yang diberikan oleh pihak bank jika berdasarkan jaminan deposito, dibatasi oleh nilai dari jaminan krdit itu sendiri.

Penyesuaian antara fasilitas kredit yang akan diberikan dengan nilai deposito yang dijadikan jaminan, dimana fasilitas kredit tersebut dengan jangka waktu tidak boleh melebihi nilai deposito yang dijadikan sebagai jaminan kredit.sesuai jangka waktu deposito disesuaikan dengan jangka waktu antar fasilitas kredit yang diberikan dengan jangka waktu deposito sebagai jaminan, Misalnya 6 bulan atau 1 tahun. Perjanjian yang telah dibuat tersebut sangat penting karena saling

${ }^{15}$ Sembiring, Sentosa 
Asuan, Deposito Sebagai Jaminan Kredit Berdasarkan Undang-Undang Perbankan, Halaman 351-370

terkait satu sama lainnya dan tidak bisa dipisahkan sehubungan dengan perjanjian yang diadakan antara kedua belah pihak yaitu kreditur dan debitur. Setelah menendatangani perjanjian tersebut dapat mengambil fasilitas kredit secara tunai dengan menanda tangani kwitansi, kemudian kwitansi tersebut diserahkan kepada petugas bank untuk diperiksa, dan nasabah menujukkan itu pada teller (kasir). Setelah diteliti keabsahannya lalu dibayarkan pada nasabah. Dalam praktek, pelaksanaan pemberian kredit dengan jaminan Deposito mulai dari permohonan kredit sampai dengan pencairan dana hanya memerlukan waktu $1 / 2$ hari saja. Pemilik deposito tidak lagi menerima bunga depositonya mulai tanggal penanda tanganan perjanjian tersebut, dananya disimpan oleh bank untuk periode bunga yang akan datang sebagai bunga kredit atas pinjaman kridit tersebut bila diperjanjikan dan hanya bayar bunga kredit $2 \%$ saja dari pinjaman. ${ }^{16}$

Pembayaran kredit oleh debitur bisa dilakuakan dengan cicilan atau

16 Rachmadi Usman, Hukum Perbankan (Jakarta: PT. Gramedia Pustaka Utama, 2003). angsuran perbulan, semesteran (per 6 bln), dan bisa dilakukan pembayaran secara keseluruhan untuk melunasi utangnya sedangkan bunga kredit sudah langsung masuk pada bank.

Pemberlakuan bentuk perjanjian dibidang perkreditan merupakan pelaksanaan asas kehati-hatian dalam hubungan hukum antara bank dan nasabah debitur. Dengan kata lain perjanjian kredit dalam hubungan hukum antara bank dan debitur, tujuannya adalah :

a. Untuk menjamin kepercayaan nasabah penjamin dan terhadap bank tempat dananya disimpan.

b. Mencegah kemungkinan terjadinya kredit macet yang dapat merugikan bank.

Adapun pemberlakuan bentuk perjanjian kredit yang bersifat baku dalam hubungan hukum antara bank, dan deebitur tujuannya adalah:

a. Untuk menyeragamkan isi dari klausula-klasula perjanjian kredit pada bank

b. Untuk kepraktisan dari bagian legal Bank dalam melakukan pengikatan kredit.

Berdasarkan Pasal 8 UU Perbankan menyebutkan dalam 
Asuan, Deposito Sebagai Jaminan Kredit Berdasarkan Undang-Undang Perbankan, Halaman 351-370

pemberian kredit bank berlakunya asas kepercayaan, asas kerahasiaan, dan asas kehati-hatian dalam hubungan antara bank dan debitur yang menyebabkan pihak bank sangat berhati-hati dalam memberikan kredit kepada debitor. Sehubungan dengan pelaksanaan perjanjian kredit dengan jaminan deposito, penjamin diberi formulirformulir yang sudah dipersiapkan oleh bank berupa: perjanjian gadai deposito; perjanjian kredit dan formulir permohonan pemblokiran.

Disamping itu pihak bank hanya menanyakan hal hal yang kurang jelas saja, dan sebaliknya pihak penjamin juga tidak berusaha untuk menanyakan kepada pihak bank isi dari perjanjian - perjanjian tersebut dengan alasan bahwa mereka sudah memberikan kepercayaan penuh kepada pihak bank untuk mengurus keseluruhan pengikatannya, sehingga mereka hanya menyetujui saja dengan menendatangani perjanjian perjanjian tersebut dengan pemahaman bahwa perjanjian yang mereka tandatangani tersebut merupakan perjanjian yang baku dari pihak bank, karena bentuk perjanjian yang ada telah terformat ( form ) dan tinggal mengisi blangko yang masih kosong yang sengaja dibuat pihak bank untuk mengisi data data seperti identitas peminjam, fasilitas kredit, pemberitahuan penutup, tandatangan dan materai.

\section{B. Penyelesaian Terhadap Debitur Wanprestasi Perjanjian Kredit Jaminan Deposito}

Menurut Yahya Harahap wanprestasi adalah sebagai pelaksanaan kewajiban yang tidak tepat pada waktunya atau tidak dilakukan menurut selayaknya, sehingga menimbulkan keharusan bagi pihak debitur untuk memberikan atau membayar ganti rugi, atau adanya wanprestasi oleh salah satu pihak, dengan pihak yang lainnya dapat menuntut pembatalah perjanjian. ${ }^{17}$

Wanprestasi diatur di dalam Pasal 1238 KUH Perdata yang menyatakan bahwa: "Si berutang adalah lalai, apabila ia dengan surat perintah atau dengan sebuah akta sejenis itu telah dinyatakan lalai, atau demi perikatannya sendiri, ialah jika ini menetapkan, bahwa si berutang harus dianggap lalai dengan lewatnya waktu yang ditentukan."

Dimaksud dengan seorang debitur dianggap wanprestasi apabila ia tidak memenuhi kewajibannya atau terlambat memenuhinya atau memenuhi

17 M.Yahya Harahap, Segi-Segi Hukum Perjanjian (Bandung: Penerbit Alumni, 1986). 
Asuan, Deposito Sebagai Jaminan Kredit Berdasarkan Undang-Undang Perbankan, Halaman 351-370

tetapi tidak seperti yang telah diperjanjikan dalam akad perjanjian yang telah dibuat sebelumnya, dimana kelalaian atau wanprestasi tersebut harus dinyatakan terlebih dahulu secara resmi dalam suatu pernyataan lalai dengan cara memperingatkan (somasi) pihak yang lalai untuk melaksanakan kewajibannya. ${ }^{18}$

Untuk mengetahui sejak kapan debitur itu wanprestasi, perlu diperhatikan apakah dalam perjanjian itu ditentukan tenggang waktu pelaksanaan pemenuhan prestasi atau tidak. Dalam hal tenggang waktu yang tidak ditentukan maka diperlukan suatu tindakan hukum dari bank berupa teguran atau somasi kepada debitur. Somasi ini dimaksudkan untuk teguran bahwa debitur telah lalai memenuhi prestasi dan karenanya ia diingatkan agar dalam tenggang waktu tertentu (disebutkan dalam somasi), debitur harus segera melaksanakan prestasinya. Ketidaktaatan debitur dalam memenuhi prestasinya sesuai tanggal yang ditentukan dalam somasi, maka dalam hal ini debitur telah dinyatakan wanprestasi. ${ }^{19}$

\footnotetext{
18 Dewi Nurul Mustjari, Penyelesaian Sengketa
Dalam Praktik Perbankan Syariah (Yogyakarta:

Dalam Praktik Perbankan Syariah (Yogyakarta: PratamaPublishing, 2012).
}

19 Salim, H.S, Hukum Kontrak Teori dan
Umunya sebelum debitur masuk ke dalam status wanprestasi pasti sebelumnya debitur dianggap masuk ke dalam kriteria kredit bermasalah yang lama-lama berangsur menjadi kredit macet. Kredit bermasalah seringkali dipersamakan dengan kredit macet, padahal keduanya memiliki pengertian yang berbeda. Kredit bermasalah adalah kredit dengan kolektibilitas macet ditambah dengan kredit-kredit yang memiliki kolektibilitas diragukan yang mempunyai potensi menjadi macet. Sedangkan kredit macet adalah kredit yang agsuran pokok dan bunganya tidak dapat dilunasi selama lebih dari 2 (dua) masa angsuran ditambah 21 (dua puluh satu) bulan, atau penyelesaian kredit telah diserahkan kepada pengadilan/BUPLN atau telah diajukan ganti rugi kepada perusahaan asuransi kredit. Dengan demikian kredit macet merupakan kredit bermasalah, tetapi kredit bermasalah belum/tidak seluruhnya merupakan kredit macet. ${ }^{20}$

Hal ini disebabkan oleh dua unsur sebagai berikut:

Teknik Penyusunan Kontrak (Jakarta: Sinar Grafika, 2010).

20 Rahman,Hasanuddin, Aspek-Aspek Hukum Pemberian Kredit Perbankan Di Indonesia (Bandung: PT.Citra Aditya Bakti, 1995). 
Asuan, Deposito Sebagai Jaminan Kredit Berdasarkan Undang-Undang Perbankan, Halaman 351-370

1. Dari pihak perbankan,artinya dalam melakukan analisisnya, pihak analisis kurang teliti sehinggga apa yang seharusnya terjadi tidak dapat diperkirakan sebelumnya. Hal ini dapat pula terjadi akibat kerjasama dari pihak analisis kredit dengan pihak debitur sehingga dalam melakukan analisisnya, dilakukan secara subjektif.

2. Dari pihak nasabah ,yaitu kemacetan kredit dapat dilakukan akibat dua hal yaitu: adanya unsur kesengajaan, artinya nasabah secara sengaja bermaksud tidak membayar kewajibannya sehingga kredit yang diberikan macet. Adanya unsur tidak sengaja, artinya debitur mau membayar, tetapi tidak mampu. Sebagai contoh kredit yang dibiayai mengalami musibah seperti kebakaran, kena hama, kebanjiran sehingga kemampuan untuk membayar kredit.

Penanganan kredit perbankan yang bermasalah menurut ketentuan Surat Edaran Bank Indonesia No. 23/12/ BPP tanggal 28 Februari 1991 dalam usaha mengatasi kredit bermasalah, pihak bank dapat melakukan beberapa tindakan penyelamatan sebagai berikut:
1. Melalui rescheduling (penjadwalan kembali), yaitu suatu upaya hukum untuk melakukan perubahan terhadap beberapa syarat perjanjian kredit yang berkenaan dengan jadwal pembayaran kembali/ jangka waktu kredit termasuk tenggang (grace period), termasuk perubahan jumlah angsuran. Bila perlu dengan penambahan kredit.

2. Melalui reconditioning (persyaratan kembali), yaitu melakukan perubahan atas sebagian atau seluruh persyaratan perjanjian, yang tidak terbatas hanya kepada perubahan jadwal angsuran, atau jangka waktu kredit saja. Tetapi perubahan kredit tersebut tanpa memberikan tambahan kredit atau tanpa melakukan konversi atas seluruh atau sebagian dari kredit menjadi equity perusahaan.

3. Melalui restructuring (penataan kembali), yaitu upaya berupa melakukan perubahan syarat-syarat perjanjian kredit berupa pemberian tambaha kredit, atau melakukan konversi atas seluruh atau sebagian kredit menjadi perusahaan, yang dilakukan dengan atau tanpa rescheduling atau reconditioning. 
Asuan, Deposito Sebagai Jaminan Kredit Berdasarkan Undang-Undang Perbankan, Halaman 351-370

Upaya-upaya sebagaimana yang disebut di atas merupakan syarat represif yang mana bertujuan untuk melakukan penyelamatan kredit. Penyelamat kredit adalah suatu langkah penyelamatan kredit bermasalah melalui perundingan kekeluargaan antara pihak bankdan nasabah, sehingga pada tahap penyelamatan kredit ini belum memanfaatkan lembaga hukum karena debitur masih kooperatif.

Upaya preventif bertujuan untuk mencegah agar kredit tidak bermasalah, pada tahap ini pihak bank akan melakukan penilaian dengan seksama terhadap berbagai aspek yaitu dengan melakukan analisa kredit dengan menerapkan the five $C$ of credit analysis atau prinsip $5 \mathrm{C}$.

Apabila upaya-upaya tadi tidak bisa diterapkan maka tahap selanjutnya yaitu pihak bank akan melakukan tindakantindakan, meliputi;

1. Surat peringatan.

2. Surat Somasi.

3. Eksekusi.

Akibat hukum dari debitur yang melakukan wanprestasi adalah hukuman atau sanksi berupa :

1. Membayar kerugian yang diderita oleh kreditur (ganti rugi).

2. Pembatalan perjanjian.
3. Peralihan resiko. Benda yang dijanjikan obyek perjanjian sejak saat tidak dipenuhinya kewajiban menjadi tanggung jawab dari debitur.

4. Membayar biaya perkara, kalau sampai diperkarakan di depan hakim

$\begin{array}{cccc}\text { Jika } & \text { debitur } & \text { tetap } & \text { tidak } \\ \text { menunjukkan } & \text { itikad } & \text { baik } & \text { dalam }\end{array}$
penyelesaiannya maka selanjutnya kreditur melakukan penanganan lebih melalui upaya yang lebih bersifat pemakaian kelembagaan hukum,yaitu diantaranya:

1. Melalui Badan Peradilan mengajukan gugatan yaitu pengadilan negeri dan selanjutnya;

2. Melalui Panitia Urusan Piutang Negara dan Badan Urusan Piutang Negara; UU Nomor 49 Tahun 1960 Tentang Panitia Urusan Piutang Negara. PUPN bertugas menyelesaikan piutang negara yang telah diserahkan kepadanya oleh instansi pemerintah atau badanbadan negara.

Dengan demikian bagi bank milik negara penyelesaian kredit macetnya harus dilakukan melalui Panitia Urusan Piutang Negara 
Asuan, Deposito Sebagai Jaminan Kredit Berdasarkan Undang-Undang Perbankan, Halaman 351-370

(PUPN), dimana dengan adanya penyerahan piutang macet kepada badan tersebut secara hukum wewenang penguasaan atas hak tagih dialihkan kepadanya. Penyerahan piutang macet ini dalam Keputusan Menteri Keuangan No.293/KMK.09/1993 tanggal 27 Febuari 1993 tentang Pengurusan Piutang Negara disebut Pengalihan Pengurusan Piutang Negara.

Apabila dalam hal debitur wanprestasi ini kreditur menempuh dengan jalur badan peradilan maka sebelum melakukan eksekusi barang jaminan, debitur harus terlebih dahulu dinyatakan wanprestasi, yang dilakukan melalui putusan pengadilan. Untuk itu kreditur harus menggugat debitur atas dasar wanprestasi. Akan tetapi sebelum menggugat debitur, kreditur harus melakukan somasi terlebih dahulu yang isinya agar debitur memenuhi prestasinya.

Apabila debitur tidak juga memenuhi prestasinya, maka kreditur dapat menggugat debitur atas dasar wanprestasi, dengan mana apabila pengadilan memutuskan bahwa debitur telah wanprestasi, maka kreditur dapat melakukan eksekusi atas barang jaminan yang diberikan oleh debitur.

\section{KESIMPULAN}

Berdasarkan pasal 1 angka 7 UU Perbankan bahwa deposito dapat dijaminakan dalam pemberian kredit yang tidak boleh melebih $95 \%$ nilai deposito dengan waktu kreditnya 60 bulan paling lama.

Terjadinya wanprestasi menurut Pasal 1238 KUH Perdata, kreditur pemberi kredit melakukan perbuatan hukum yaitu surat peringatan, surat somasi dan eksekusi, penyelesaian melalui gugatan ke Pengadilan dan Panitia Urusan Piutang Negara dan Badan Urusan Piutang Negara (UU Nomor 49 Tahun 1960 Tentang Panitia Urusan Piutang Negara).

\section{DAFTAR PUSTAKA}

Bambang Fitrianto, Hukum Jaminan Perjanjian Kredit Kepemilikan Rumah. Medan: Pustaka Bangsa Press, 2013.

Budi Untung, Kredit Perbankan di Indonesia. Yogyakarta: Andi, 2000.

Dewi Nurul Mustjari, Penyelesaian Sengketa Dalam Praktik Perbankan Syariah. Yogyakarta: PratamaPublishing, 2012.

Hartono Soerja Pratiknyo, Hutang Piutang. Yogyakarta: Mustika Wikasa, 1989.

Herlien Soerojo, Kepastian Hukum Hak Atas Tanah di Indonesia. Surabaya: Arkola, 2003. 
Asuan, Deposito Sebagai Jaminan Kredit Berdasarkan Undang-Undang Perbankan, Halaman 351-370

Hermansyah, Hukum Perbankan Nasional Indonesia. Jakarta: Prenana Media, 2005.

J.Satrio, Hukum Jaminan, Hak-hak Jaminan Kebendaan. Bandung: PT. Citra Aditya Bakti, 1998.

M. Bahsan, Hukum Jaminan dan Jaminan Kredit Perbankan Indonesia. Jakarta: PT. Rajagrafindo Persada, 2015.

Muhamad Djumanha, Hukum Perbankan di Indonesia. Bandung: Citra Aditya Bakti, Bandung, 1996.

M.Yahya Harahap, Segi-Segi Hukum Perjanjian. Bandung: Penerbit Alumni, 1986.

O. P. Simorangkir, Kamus Perbankan. Jakarta: Bina Aksara, 1989.

Rachmadi Usman, Hukum Perbanka. Jakarta: PT. Gramedia Pustaka
Utama, 2003.

Rahman, Hasanuddin, Aspek-Aspek Hukum Pemberian Kredit Perbankan Di Indonesia. Bandung: PT.Citra Aditya Bakti, 1995.

Salim, HS, Perkembangan Hukum Jaminan di Indonesia. Jakarta: PT. Rajagrafindo Persada, 2004.

Salim, H.S, Hukum Kontrak Teori dan Teknik Penyusunan Kontrak. Jakarta: Sinar Grafika, 2010.

Sembiring, Sentosa, Hukum Perbankan. Bandung: CV Mandar Maju, 2008.

Sihombing, Jonker, Penjaminan Simpanan Nasabah Perbankan. Bandung: PT. Alumni, Bandung, 2010. 